\title{
Lysine-Specific Histone Demethylase 1A
}

National Cancer Institute

\section{Source}

National Cancer Institute. Lysine-Specific Histone Demethylase 1A. NCI Thesaurus. Code C78143.

Lysine-specific histone demethylase 1A (852 aa, 93 kDa) is encoded by the human KDM1A gene. This protein is involved in both histone demethylation and transcriptional regulation. 